\title{
DOKŁADNOŚĆ WYZNACZANIA POZYCJI Z ZASTOSOWANIEM PERMANENTNYCH USLUG INTERNETOWYCH PPP (PRECISE POINT POSITIONING)
}

\begin{abstract}
Precyzyjne pozycjonowanie PPP to metoda wyznaczania pozycji przy pomocy samodzielnego odbiornika GNSS. Może stanowić alternatywną technikę do pomiarów różnicowych gdzie niezbędnym jest utrzymanie łączności z pojedynczą stacją RTK lub regionalną siecią stacji referencyjnych RTN. Metoda precyzyjnego pomiaru PPP może w szczególności sprawdzić się w obszarach o słabo rozwiniętej infrastrukturze stacji naziemnych. W niniejszej pracy przedstawiono wyniki analizy dokładności precyzyjnego wyznaczania pozycji na wierzchołkach trójkątnej osnowy dla obserwacji trwających od 0,5 do 6 godzin z wykorzystaniem bezpłatnych permanentnych usług internetowych realizujących obliczenia techniką PPP jak: APPS, CSRS-PPP, magicGNSS. Dla każdego punktu osnowy pomiarowej wykonano obliczenia wykorzystując obserwacje GPS i uwzględniając produkty Final. Wykonano ocenę wpływu dokładności jednoczesnego pozycjonowania trzech punktów osnowy pomiarowej na zmianę odległości zredukowanej i wysokości względnej między wierzchołkami badanego trójkąta osnowy.
\end{abstract}

Słowa kluczowe: GPS, APPS, CSRS-PPP, GMV, magicGNSS

\section{Wprowadzenie}

Precise Point Positioning (PPP) to technika satelitarnego precyzyjnego pozycjonowania absolutnego, której najważniejszą zaletą jest możliwość wyznaczenia pozycji z dużą dokładnością za pomocą tylko jednego dwuczęstotliwościowego odbiornika GNSS przy jednoczesnym braku łączności z regionalną siecią lub pojedynczą stacją referencyjną [1-4, 6, 11-14]. Metoda precyzyjnego pomiaru PPP wyklucza konieczność utrzymania kosztownej regionalnej sieci stacji referencyjnych RTN oraz pozwala na wykonywanie pomiarów w obszarach o słabo rozwiniętej infrastrukturze naziemnej. Wysokie dokładności pozycjonowania możliwe są do uzyskania przy wykorzystaniu precyzyjnych produktów udostępnianych przez międzynarodową służbę IGS (International GNSS

\footnotetext{
${ }^{1}$ Marcin Malinowski, Uniwersytet Technologiczno-Przyrodniczy im. J. i J. Śniadeckich, Katedra Geomatyki i Gospodarki Przestrzennej, Al. prof. S. Kaliskiego 7, 85-796 Bydgoszcz; marcinm@utp.edu.pl
} 
Service), takich jak parametry: ruchu obrotowego Ziemi, zegarów satelitów oraz orbit satelitów. Jakość powyższych produktów pozwala służbie IGS na wypełnianie podstawowych zadań jak m.in. realizacja globalnego, precyzyjnego układu odniesienia, badania ruchu obrotowego Ziemi, ruchu biegunów i zjawisk pływowych, badania zmian poziomu mórz i oceanów, badania atmosfery (jonosfery i troposfery). Proces opracowywania precyzyjnych produktów IGS wspomaga ośrodek naukowy Jet Propulsion Laboratory, który jednocześnie udostępnia własne produkty dotyczące zegarów oraz orbit satelitów.

Służba IGS realizuje swoje zadania dzięki ok. 350 permanentnych stacji śledzących, globalnych i regionalnych centrów danych, licznych centrów analiz. Przy realizacji pomiarów techniką PPP chociaż nie jest wymagana łączność $\mathrm{z}$ regionalną siecią lub stacją referencyjną to niezbędnym jest dostęp do precyzyjnych produktów udostępnianych przez służbę IGS, a powstających w oparciu o globalną sieć permanentnych stacji śledzących.

Wysoką dokładność pozycjonowania w technice PPP uzyskuje się przez uwzględnienie szeregu dodatkowych danych i poprawek [5]. Najważniejsze znaczenie mają tu precyzyjne orbity i poprawki zegarów satelitów. Przy opracowywaniu pomiarów uwzględnia się także poprawkę jonosferyczną i troposferyczną, pływy oceanów i skorupy ziemskiej, położenie centrum fazowego anteny satelity i odbiornika oraz efekty wynikające z teorii względności.

Metoda obliczeniowa precyzyjnego pozycjonowania absolutnego jest dość dobrze opisana w literaturze $[4,5]$. Oparta jest ona na obserwacjach kodowych jak i fazowych na obydwu częstotliwościach. Równania obserwacji kodowych i fazowych na częstotliwości L1 można zapisać w następujący sposób [4, 12, 13]:

$$
\begin{aligned}
& P_{1, i}^{k}=\rho_{i}^{k}+c\left(\Delta t_{i}-\Delta t^{k}\right)+\delta O^{k}+\delta T_{i}^{k}+\delta I_{i}^{k}+\varepsilon \\
& \Phi_{1, i}^{k}=\rho_{i}^{k}+c\left(\Delta t_{i}-\Delta t^{k}\right)+\delta O^{k}+\delta T_{i}^{k}-\delta I_{i}^{k}+\lambda_{L 1} N_{L 1, i}^{k}+\varepsilon
\end{aligned}
$$

gdzie:

$P_{1, i}^{k} \quad$ - pseudoodległość od satelity k do odbiornika i na częstotliwości L1 [m],

$\Phi_{1, i}^{k}$ - obserwacja fazowa odbiornika i od satelity k na częstotliwości L1 [m],

$\rho_{i}^{k} \quad$ odległość geometryczna między satelitą k a odbiornikiem i [m],

$\Delta t_{i}, \Delta t^{k}$ - błędy zegarów odbiornika i oraz satelity k [s],

$\delta O^{k}-$ błąd orbity dla satelity k [m],

$\delta T_{i}^{k}$ - opóźnienie sygnału spowodowane refrakcją troposferyczną [m],

$\delta I_{i}^{k}$ - opóźnienie sygnału spowodowane refrakcją jonosferyczną [m],

$N_{L 1, i}^{k}$ - całkowita liczb pełnych odległości fal sygnału na L1, nieoznaczoność,

$\lambda_{L 1}$ - długość fali elektromagnetycznej na częstotliwości L1 [m],

$c \quad$ - prędkość światła w próżni $[\mathrm{m} / \mathrm{s}]$,

$\varepsilon \quad-$ błędy przypadkowe [m]. 
Wielkości wyznaczane w procesie obliczeń to współrzędne odbiornika, błąd zegara odbiornika, opóźnienie troposferyczne oraz nieoznaczoność. Błąd efemeryd i błąd zegara satelity redukuje się korzystając np. z precyzyjnych produktów IGS. Błąd opóźnienia jonosferycznego najczęściej można wyeliminować stosując odbiorniki dwuczęstotliwościowe [4]. Zatem eliminację refrakcji jonosferycznej można osiągnąć przez zastosowanie kombinacji liniowej typu ionosphere-free dla obserwacji kodowych i fazowych. Natomiast opóźnienie troposferyczne nie zależy od częstotliwości sygnału GNSS, stąd jest traktowane jako dodatkowa niewiadoma [7]. Wyznaczenie liczby pełnych cykli fazowych sygnału GNSS czyli nieoznaczoności fazy jest niezwykle trudne w pomiarach bezwzględnych. Określenie wartości tej niewiadomej wymaga długotrwałych obserwacji $[7,8]$.

Opracowanie obserwacji satelitarnych techniką PPP można wykonać z pomocą specjalistycznego oprogramowania, którego przykładem jest Bernese GPS Software, EZSurv lub pakiet otwartego oprogramowania RTKLib. Alternatywnym rozwiązaniem jest zastosowanie permanentnych usług internetowych wykonujących obliczenia techniką PPP (Tabela 1).

Tabela 1. Usługi on-line udostępniające obliczenia techniką PPP

Table 1. Online services for calculations using PPP

\begin{tabular}{|c|c|c|}
\hline $\begin{array}{l}\text { Skrót } \\
\text { nazwy }\end{array}$ & Pelna nazwa usługi & Podmiot udostępniający usługę \\
\hline CSRS-PPP & $\begin{array}{c}\text { Canadian Spatial Reference } \\
\text { System Precise Point Positioning }\end{array}$ & Natural Resources Canada (NRCan) \\
\hline APPS & Automatic Precise Positioning Service & NASA - Jet Propulsion Laboratory (JPL) \\
\hline GAPS & $\begin{array}{l}\text { GNSS Analysis and Positioning } \\
\text { Software }\end{array}$ & University of New Brunswick (UNB) \\
\hline magicGNSS & $\begin{array}{l}\text { magicPPP - Precise Point Positioning Solu- } \\
\text { tion }\end{array}$ & $\begin{array}{l}\text { GMV Aerospace and Defence S.A.U. } \\
\text { (GMV) }\end{array}$ \\
\hline
\end{tabular}

Wykaz w tabeli 1 otwiera usługa CSRS-PPP (Canadian Spatial Reference System), która pozwala na opracowanie danych w trybie statycznym i kinematycznym z wykorzystaniem precyzyjnych poprawek orbit i zegarów satelitów udostępnianych przez IGS. Obliczenia mogą być realizowane na podstawie obserwacji kodowych i fazowych z jednej lub dwóch częstotliwości. Jest możliwość określenia układu odniesienia NAD83 lub ITRF2008 dla wyznaczanych współrzędnych. Istnieje również możliwość dołączenia pliku z danymi o pływach oceanów. Do opracowania danych mogą być wykorzystane obserwacje z konstelacji GPS i GLONASS. Korzystanie z usługi wiąże się z koniecznością rejestracji.

Usługi APPS (Automatic Precise Positioning Service) i GAPS (GNSS Analysis and Positioning Software) mogą wykonywać obliczenia w trybie statycznym i kinematycznym. Usługa GAPS wymaga rejestracji, natomiast APPS nie stawia takiego wymogu. W przypadku usługi APPS wykonanie rejestracji po- 
zwala dodatkowo na zmiany opcji przetwarzania obserwacji oraz zwiększenie limit przesyłanego pliku z 5 MB do $10 \mathrm{MB}$. Usługa GAPS korzysta z produktów Final, Rapid i Ultra-Rapid dla poprawek orbit i zegarów satelitów udostępnianych przez IGS i NRCan (Natural Resources Canada). Natomiast APPS używa produktów JPL (Jet Propulsion Laboratory) typu final, rapid i ultra-rapid dla poprawek orbit i zegarów satelitów. Osoby korzystające $\mathrm{z}$ usługi GAPS mogą przesłać plik z danymi o pływach skorupy ziemskiej i oceanów oraz plik z parametrami kalibracji anteny. Usługa APPS nie uwzględnia w obliczeniach parametrów centrum fazowego anteny. Użytkownicy APPS do opracowania danych mogą wykorzystać wyłącznie obserwacje z konstelacji GPS natomiast w przypadku usługi GAPS z konstelacji GPS, Galileo i BeiDou.

Usługa magicGNSS udostępniana jest za pośrednictwem interaktywnego portalu internetowego oraz e-maila. Pierwszy sposób komunikacji wymaga rejestracji. W trakcie obliczeń można przetwarzać dane zebrane w trybie statycznym i kinematycznym na dwóch częstotliwościach wykorzystując produkty final, rapid dla poprawek orbit i zegarów satelitów udostępnianych przez IGS i GMV. Do opracowania danych można wybrać obserwacje z konstelacji GPS, GLONASS, Galileo, BeiDou i QZSS. Współrzędne obliczonej pozycji wyznaczane są w dwóch układach odniesienia ITRF2008 oraz ETRS89. Usługa nie uwzględnia w obliczeniach parametrów centrum fazowego anteny.

\section{Metodyka badań}

Celem badań terenowych była ocena dokładności wyznaczania pozycji wierzchołków trójkątnej osnowy pomiarowej z wykorzystaniem różnych usług PPP dostępnych w Internecie. Do realizacji obliczeń zastosowano trzy najważniejsze i ciaggle rozwijane usługi opracowywania obserwacji GNSS z wykorzystaniem techniki PPP tj. APPS, CSRS-PPP, magicGNSS (Tab. 1). Usługę GAPS wykluczono z uwagi na liczne błędy w trakcie wykonywania obliczeń.

Uwzględniając dobre warunki widoczności satelitów nad horyzontem w niedalekim sąsiedztwie budynku 3.1 na terenie kampusu Uniwersytetu Techniczno-Przyrodniczego zostały założone trzy punkty osnowy pomiarowej (Rys. 1). Niezmienność pozycji każdego punktu osnowy zapewniono przy pomocy masywnego i głębokiego fundamentu, posadowionego poniżej głębokości przemarzania. Na szczycie słupa zakotwiono metalowy sześcian z centralnym otworem $5 / 8$ " służącym do mocowania instrumentów pomiarowych.

Do przeprowadzenia pomiarów wykorzystano dwa odbiorniki GR-5 firmy Topcon oraz jeden Triumph-VS firmy Javad. W trakcie każdej sesji odbiorniki instalowano $\mathrm{w}$ jednakowej konfiguracji gdzie GR-5 ustawiano na punktach 1 i 3 natomiast Triumph-VS na punkcie 2. Pomiary terenowe trwały przez 6 dni w formie 6 godzinnych sesji pomiarowych. W ten sposób każdego dnia powstawał zapis na 3 punktach co w sumie dało 18 sesji. 

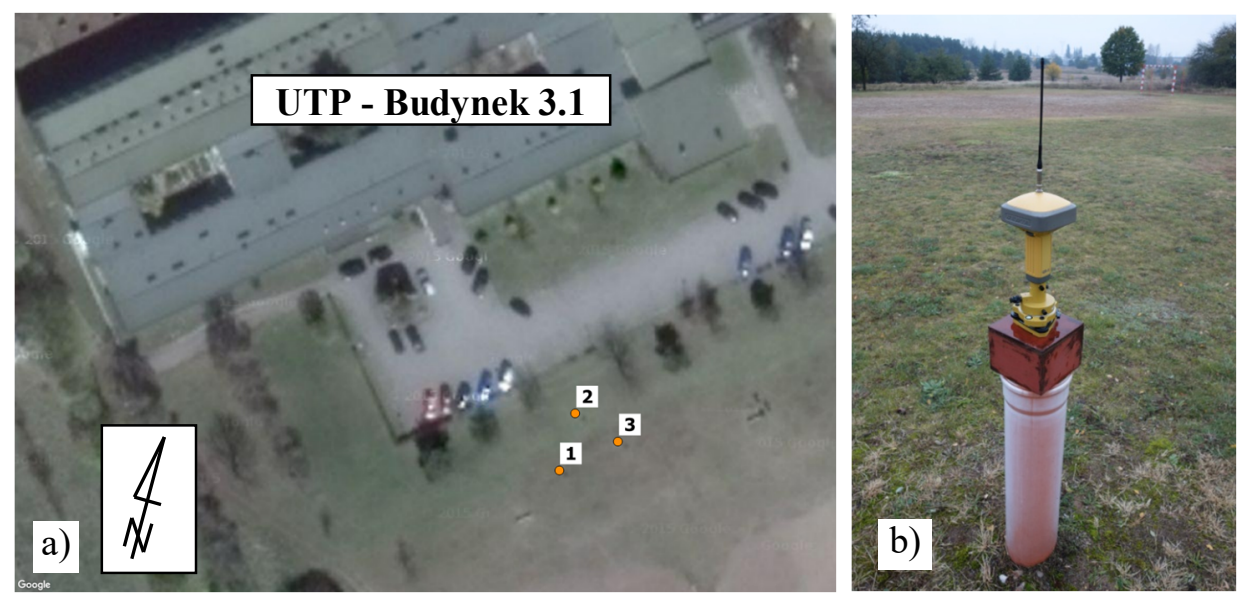

Rys. 1. Lokalizacja trzech punktów osnowy pomiarowej w pobliżu budynku 3.1 na terenie kampusu Uniwersytetu Technologiczno-Przyrodniczego (źródło ortofotomapy: Google Maps)

Fig. 1. Localization of: a) three points of geodesy test network in the vicinity of UTP Building 3.1. (Source: Google Maps); b) pole for attaching measurement instruments

Do obliczeń wykorzystano dane obserwacyjne z konstelacji GPS o interwale 1 sekundy. Obserwacje jako pomiary statyczne podczas sesji pomiarowych były rejestrowane w pamięci wewnętrznej odbiorników.

Proces opracowania danych rozpoczęto od konwersji plików sesji pomiarowych z binarnego formatu Javad (*.jps) i Topcon (*.tps) do uniwersalnego formatu wymiany danych RINEX 2.11. Następnie z pomocą specjalnie przygotowanych skryptów ze zgromadzonych pomiarów utworzono pliki obserwacyjne o długości: $0.5,1,2,3$ godzin. W rezultacie otrzymano 216 sesji półgodzinnych, 108 sesji jednogodzinnych, 54 sesje dwugodzinne i 36 sesji trzygodzinnych. $\mathrm{Z}$ uwagi na ograniczenie wielkości przesyłanych plików obserwacyjnych do 10MB dla usługi APPS przy pomocy skryptu utworzono pliki obserwacyjne $\mathrm{z}$ interwałem 5 sek. Parametry zastosowane $\mathrm{w}$ trakcie obliczeń przez poszczególne usługi PPP przedstawiono w tabeli 2.

Kolejnym krokiem opracowania była transformacja współrzędnych obserwowanego punktu z układu ITRF2008 do ETRF89, a następnie do układu współrzędnych płaskich $2000 \mathrm{w}$ strefie 6 na podstawie [9]. Uwzględniono model centrum fazowego anteny w przypadku, gdy usługodawca metody PPP nie zastosował go w wynikach końcowych opracowania.

Dla każdego punktu osnowy pomiarowej wykonano obliczenia wykorzystując wyłącznie obserwacje GPS oraz uwzględniając produkty final. Uzyskane współrzędne porównano ze współrzędnymi referencyjnymi. Z uwagi na brak dobowych sesji pomiarowych do przeprowadzenia oceny dokładności pozycji pojedynczego punktu osnowy wykorzystano opracowanie obserwacji w trybie post-processingu z 6 najbliższych stacji referencyjnych sieci Leica SmartNet. 
Tabela 2. Parametry przyjęte przez usługi on-line udostępniające obliczenia metodą PPP

Table 2. Parameters adopted by online services for calculations with PPP

\begin{tabular}{|c|c|c|c|}
\hline Parametr & APPS & CSRS-PPP & magicGNSS \\
\hline Wersja & v5 & 1.0511216 & $?$ \\
\hline Tryb obliczeń & static & static & static \\
\hline Konstelacja & GPS & GPS & GPS \\
\hline Częstotliwość & L1,L2 & L1,L2 & L1,L2 \\
\hline Rodzaj obserwacji & kodowe i fazowe & kodowe i fazowe & kodowe i fazowe \\
\hline Model anteny & nieuwzględniony & uwzględniony & nieuwzględniony \\
\hline Układ odniesienia & ITRF2008 & ITRF2008 & ITRF2008, ETRF89 \\
\hline Orbity i zegary satelitów & JPL Final & IGS Final & IGS Final \\
\hline Pływy oceanów & tak & nie & tak \\
\hline Pływy skorupy ziemskiej & tak & tak & tak \\
\hline Odcięcie horyzontu & $7,5^{\circ}$ & $10^{\circ}$ & $10^{\circ}$ \\
\hline
\end{tabular}

Obliczenia wykonano przy pomocy oprogramowania EZSurv z wykorzystaniem najbliższych stacji referencyjnych, do których wyznaczone wektory spełniają kryteria dokładnościowe. Na podstawie wybranych punktów zrealizowano wyrównanie, którego wynikiem są współrzędne obserwowanego punktu w układzie ITRF2008. Następnie współrzędne poddano transformacji z układu ITRF2008 do ETRF89, a później do układu współrzędnych płaskich 2000 w strefie 6 . W obliczeniach uwzględniono model centrum fazowego anteny. Porównanie wielkości pomierzonych $\mathrm{z}$ wielkościami referencyjnymi wykonano w układzie 2000. Metoda transformacji układów współrzędnych ma zbliżony wpływ na dokładność przeprowadzonych testów w punktach osnowy pomiarowej z uwagi na rozmieszczenie ich w odległościach nieprzekraczających $12 \mathrm{~m}$.

a)

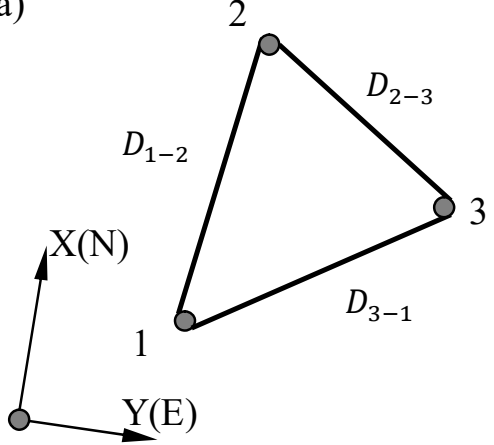

b)

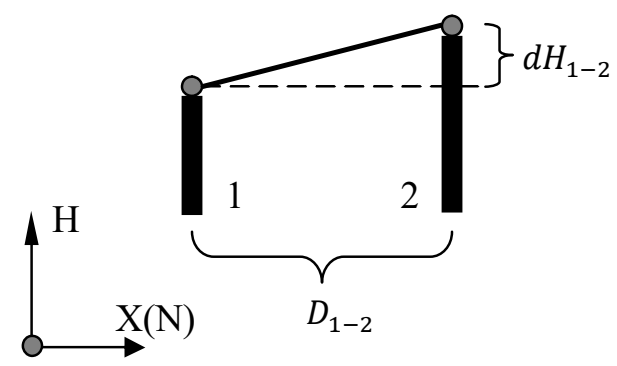

Rys. 2. Schemat lokalizacji punktów osnowy pomiarowej na: a) planie sytuacyjnym, b) przekroju między punktami 1-2

Fig. 2. Scheme of localization of points of geodesy test network on: a) horizontal plane, b) schematic cross-section between points 1 and 2 
Po wykonaniu post-processingu przy obliczeniach uzyskano średnie błędy wyznaczenia składowych pozycji horyzontalnej w przedziale między $m_{p}=0,004 \mathrm{~m}$ a $m_{p}=0,006 \mathrm{~m}$ oraz wysokości w przedziale między $m_{H}=0,007 \mathrm{~m}$ a $m_{H}=0,014 \mathrm{~m}$. Ponadto, analizie poddano średnie wartości odchyłek składowych pozycji od wielkości referencyjnych, ich odchyłki maksymalne oraz udział procentowy odchyłki w dopuszczalnym przedziale dla przebadanej próby.

Przeprowadzono również eksperyment, mający na celu określenie dokładności wyznaczania odległości zredukowanej i wysokości względnej między punktami osnowy pomiarowej. Za wielkości odniesienia przyjęto wykonane przy pomocy stacji laserowej Leica TDRA6000 pomiary odległości zredukowanej i wysokości względnej między punktami osnowy pomiarowej (Tab. 3). Analizie poddano średnie wartości odchyłek odległości i wysokości względnej od wielkości referencyjnych, ich odchyłki maksymalne oraz udział procentowy odchyłki w dopuszczalnym przedziale dla przebadanej próby.

Tabela 3. Wielkości referencyjne odległości zredukowanej na płaszczyznę poziomą i wysokości względnej między punktami osnowy pomierzone przy pomocy stacji laserowej

Table 3. Reference values of reduced distance in a horizontal plane and the difference of height between points of test network measured by a laser station

\begin{tabular}{|c|c|c|c|c|c|}
\hline \multicolumn{2}{|c|}{ Odległość zredukowana $\boldsymbol{D}[\mathbf{m}]$} & \multicolumn{3}{c|}{ Wysokość względna $\boldsymbol{d} \boldsymbol{H}[\mathbf{m}]$} \\
\hline $\mathbf{1 - 2}$ & $\mathbf{2 - 3}$ & $\mathbf{3 - 1}$ & $\mathbf{1 - 2}$ & $\mathbf{2 - 3}$ & $\mathbf{3 - 1}$ \\
\hline 10.113 & 8.727 & 11.234 & 0.537 & -0.408 & -0.129 \\
\hline
\end{tabular}

\section{Wyniki opracowania sesji obserwacyjnych}

Wyniki obliczeń w postaci wartości odchyłek wypadkowej współrzędnych horyzontalnych $N E$ pozycji na punktach osnowy pomiarowej dla sesji o długości $0.5,1,2,3,6$ godz. przedstawiono odpowiednio na (Rys. 3, 5, 7, 9). Natomiast wartości odchyłek współrzędnej wysokości $H$ pozycji na punktach osnowy pomiarowej dla sesji o długości $0.5,1,2,3,6$ godz. przedstawiono odpowiednio na (Rys. 4, 6, 8, 10). Rodzaj zastosowanej permanentnej usługi internetowej PPP wyróżniono kolorem. Natomiast kształt znaczników identyfikuje numer punktu pomiarowego. Na rysunku 3 przedstawiono odchyłki wypadkowej współrzędnych horyzontalnych trzech punktów osnowy pomiarowej względem pozycji referencyjnej otrzymane z opracowania obserwacji podzielonych na półgodzinne sesje. Po analizie rysunku można zauważyć zwiększony rozrzut błędów na punkcie 2, gdzie maksymalne wartości odchyłek wynoszą: 0,971 m dla GMV. Podobnie na rysunku 4 błędy składowej wysokości o największych wartościach dotyczą punktu 2, gdzie maksymalne wartość odchyłek wynoszą: $0,434 \mathrm{~m}$ dla GMV. W przypadku sesji jednogodzinnych (Rys. 5) nadal można zauważyć zwiększony rozrzut błędów na punkcie 2, gdzie maksymalne wartości odchyłek są już dwukrotnie mniejsze i wynoszą: 0,467 m dla GMV. Dla dwóch pozosta- 
łych usług tj. APPS, CSRS wielkości błędów średnich i maksymalnych są zbliżone. Wielkości błędów maksymalnych dla sesji dwugodzinnych (Rys. 7) na punkcie 2 są zbliżone do odpowiadających im odchyłek na punktach 1 i 3. Korzystając z usług APPS lub CSRS dla sesji dwugodzinnych na punktach 2 i 3 od $89 \%$ do $100 \%$ wyznaczonych wypadkowych horyzontalnych pozycji znalazło się w przedziale $\pm 3 \mathrm{~cm}$ od pozycji referencyjnej, a od $94 \%$ do $100 \%$ obliczonych składowych wysokości zmieściło się w przedziale $\pm 6 \mathrm{~cm}$ od pozycji referencyjnej. Usługi APPS i CSRS dla sesji trzygodzinnych uzyskały od $83 \%$ do $100 \%$ wyznaczonych wypadkowych horyzontalnych pozycji $\mathrm{w}$ przedziale $\pm 3 \mathrm{~cm}$ od pozycji referencyjnej. Największy udział procentowy odchyłek wypadkowej horyzontalnej pozycji $\mathrm{w}$ przedziale $\pm 3 \mathrm{~cm}$ od pozycji referencyjnej dla sesji 6-godzinnych uzyskała usługa CSRS a dla sesji 2 i 3-godzinnych usługa APPS. Niezależnie od długości sesji pomiarowej największą dokładnością charakteryzuje się współrzędna północna (Rys. 3, 5, 7).

Tabela 4. Statystyki współrzędnych horyzontalnych $N E$ pozycji na punktach osnowy pomiarowej dla różnej długości sesji

Table 4. Statistics of horizontal coordinates $N E$ (North-East) of position on points of test network for different time session

\begin{tabular}{|c|c|c|c|c|c|c|c|c|c|c|}
\hline \multirow{2}{*}{$\begin{array}{l}\text { Nazwa } \\
\text { usługi }\end{array}$} & \multirow{2}{*}{$\begin{array}{c}\text { Długość } \\
\text { sesji } \\
{[h]}\end{array}$} & \multicolumn{3}{|c|}{$\begin{array}{l}\text { Średnie odchyłki } \\
\qquad|N E|[\mathrm{cm}]\end{array}$} & \multicolumn{3}{|c|}{$\begin{array}{l}\text { Maksymalne odchylki } \\
\qquad|N E|[\mathrm{cm}]\end{array}$} & \multicolumn{3}{|c|}{$\begin{array}{c}\text { Udzial procentowy } \\
\text { w przedziale } \pm 3 \mathrm{~cm}[\%]\end{array}$} \\
\hline & & 1 & 2 & 3 & 1 & 2 & 3 & 1 & 2 & 3 \\
\hline GMV & 0.5 & 10.9 & 28.1 & 10.3 & 29.2 & 97.1 & 30.6 & 8 & 0 & 3 \\
\hline APPS & 0.5 & 5.2 & 17.4 & 8.4 & 9.3 & 36.3 & 21.7 & 17 & 22 & 17 \\
\hline CSRS & 0.5 & 5.7 & 8.5 & 5.2 & 17.4 & 28.5 & 24.9 & 24 & 24 & 28 \\
\hline GMV & 1 & 5.6 & 13.4 & 5.9 & 15.5 & 46.7 & 19.4 & 19 & 9 & 19 \\
\hline APPS & 1 & 5.1 & 5.5 & 5.5 & 18.4 & 15.3 & 14.4 & 14 & 14 & 39 \\
\hline CSRS & 1 & 6.2 & 3.3 & 5.2 & 15.3 & 14.1 & 15.0 & 17 & 56 & 25 \\
\hline GMV & 2 & 2.6 & 3.7 & 2.0 & 5.2 & 8.0 & 6.1 & 61 & 33 & 78 \\
\hline APPS & 2 & 2.1 & 1.1 & 2.2 & 6.9 & 2.7 & 8.0 & 83 & 100 & 89 \\
\hline CSRS & 2 & 3.1 & 1.6 & 1.8 & 7.9 & 4.4 & 8.4 & 44 & 94 & 89 \\
\hline GMV & 3 & 2.8 & 1.9 & 1.9 & 5.1 & 4.7 & 5.4 & 58 & 75 & 83 \\
\hline APPS & 3 & 1.0 & 0.8 & 1.8 & 2.0 & 1.0 & 5.0 & 100 & 100 & 83 \\
\hline CSRS & 3 & 2.3 & 1.1 & 1.3 & 4.9 & 1.8 & 4.4 & 83 & 100 & 92 \\
\hline GMV & 6 & 0.6 & 0.7 & 1.3 & 1.5 & 1.1 & 1.9 & 100 & 100 & 100 \\
\hline APPS & 6 & 0.5 & 1.1 & 1.3 & 1.5 & 1.4 & 2.1 & 100 & 100 & 100 \\
\hline CSRS & 6 & 0.2 & 0.7 & 0.2 & 0.3 & 1.3 & 0.4 & 100 & 100 & 100 \\
\hline
\end{tabular}




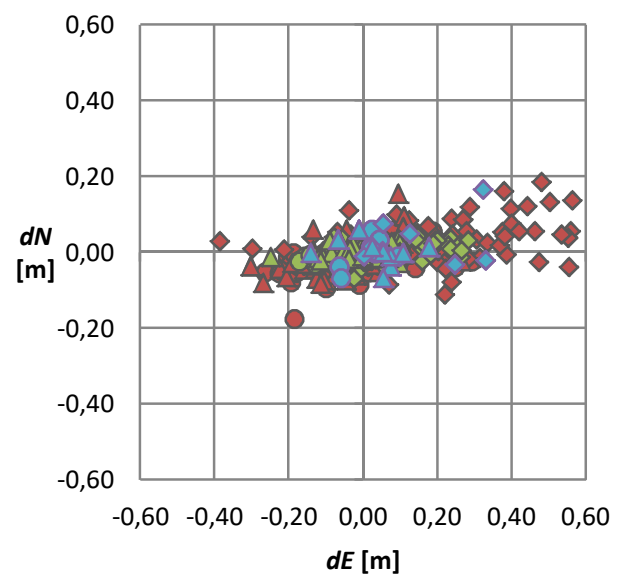

Punkt 1 - GMV Punkt 2 - GMV $\triangle$ Punkt 3 - GMV OPunkt 1 -CSRS $\triangle$ Punkt 2 -CSRS $\triangle$ Punkt 3 -CSRS

OPunkt 1 - APPS $\odot$ Punkt 2 - APPS $\triangle$ Punkt 3 - APPS

Rys. 3. Odchyłka wypadkowej współrzędnych horyzontalnych $N E$ pozycji dla sesji 0,5 godz.

Fig. 3. Deviation of the resultant $N E$ (North-East) of horizontal coordinates of position for $0,5 \mathrm{~h}$ sessions

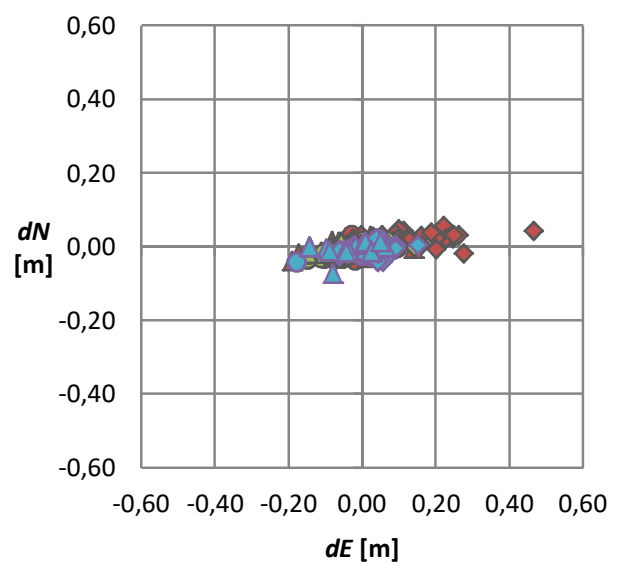

Punkt 1 -GMV $\triangle$ Punkt 2 -GMV $\triangle$ Punkt 3 -GMV OPunkt 1 -CSRS $\diamond$ Punkt 2 -CSRS $\triangle$ Punkt 3 - CSRS

OPunkt 1 - APPS $\triangle$ Punkt 2 -APPS $\triangle$ Punkt 3 -APPS

Rys. 5. Odchyłka wypadkowej współrzędnych horyzontalnych $N E$ pozycji dla sesji 1 godz.

Fig. 5. Deviation of the resultant $N E$ (North-East) of horizontal coordinates of position for $1 \mathrm{~h}$ sessions

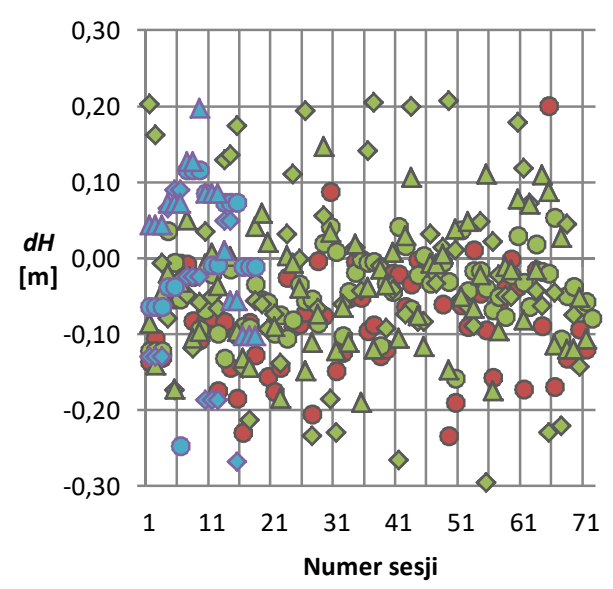

Punkt 1 - GMV Punkt 2 - GMV $\triangle$ Punkt 3 - GMV OPunkt 1 -CSRS $\triangle$ Punkt 2 - CSRS $\triangle$ Punkt 3 -CSRS

P Punkt 1 - APPS $\diamond$ Punkt 2 - APPS $\triangle$ Punkt 3 -APPS

Rys. 4. Odchyłka współrzędnej wysokości $H$ pozycji dla sesji 0,5 godz.

Fig. 4. Deviation of the height coordinate $H$ of position for $0,5 \mathrm{~h}$ sessions

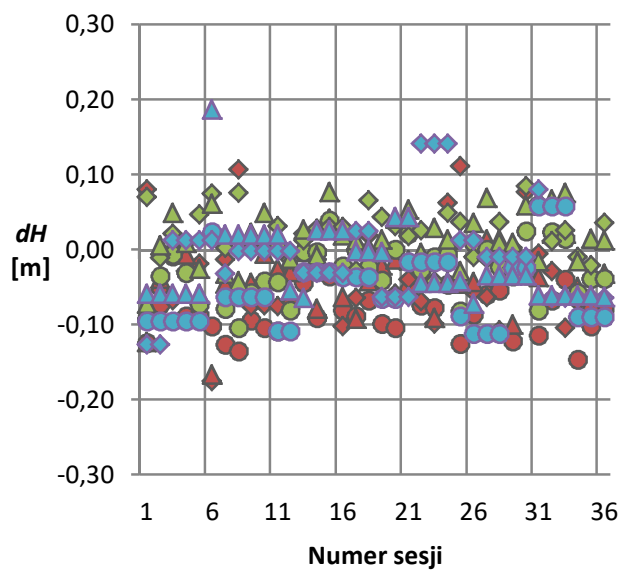

Punkt 1 -GMV $\triangle$ Punkt 2 - GMV $\triangle$ Punkt 3 -GMV OPunkt 1 -CSRS $\triangle$ Punkt 2 -CSRS $\triangle$ Punkt 3 -CSRS

OPunkt 1 - APPS $\triangle$ Punkt 2 - APPS $\triangle$ Punkt 3 - APPS

Rys. 6. Odchyłka współrzędnej wysokości $H$ pozycji dla sesji 1 godz.

Fig. 6. Deviation of the height coordinate $H$ of position for $1 \mathrm{~h}$ sessions 


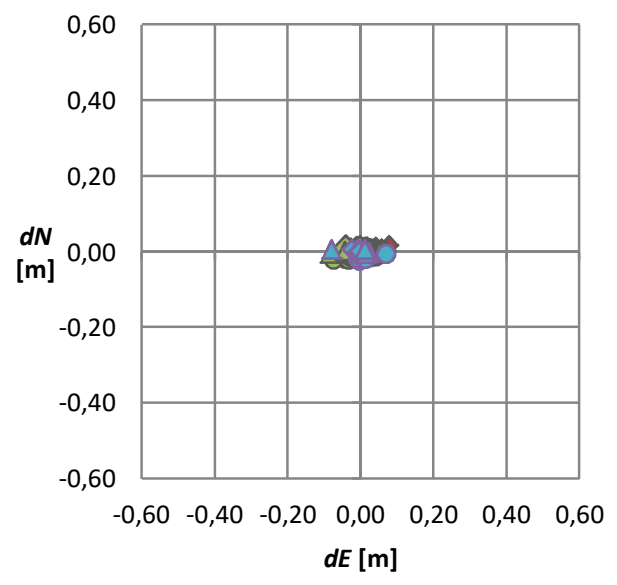

P Punkt 1 - GMV $\diamond$ Punkt 2 - GMV $\triangle$ Punkt 3 - GMV O Punkt 1 - CSRS $\triangle$ Punkt 2 - CSRS $\triangle$ Punkt 3 - CSRS

- Punkt 1 - APPS $\diamond$ Punkt 2 - APPS $\triangle$ Punkt 3 - APPS

Rys. 7. Odchyłka wypadkowej współrzędnych horyzontalnych $N E$ pozycji dla sesji 2 godz.

Fig. 7. Deviation of the resultant $N E$ (North-East) of horizontal coordinates of position for $2 \mathrm{~h}$ sessions

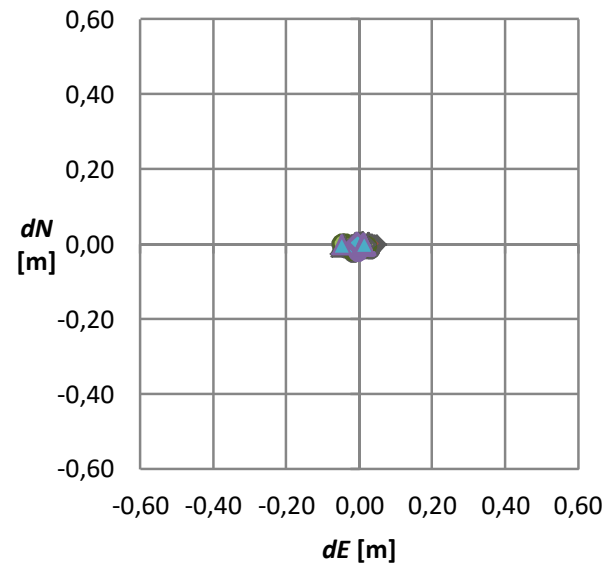

Punkt 1 - GMV Punkt 2 - GMV $\triangle$ Punkt 3 - GMV OPunkt 1 - CSRS $\diamond$ Punkt 2 - CSRS $\triangle$ Punkt 3 - CSRS Punkt 1 - APPS $\triangle$ Punkt 2 - APPS $\triangle$ Punkt 3 - APPS

Rys. 9. Odchyłka wypadkowej współrzędnych horyzontalnych $N E$ pozycji dla sesji 3 godz.

Fig. 9. Deviation of the resultant $N E$ (North-East) of horizontal coordinates of position for $3 \mathrm{~h}$ sessions

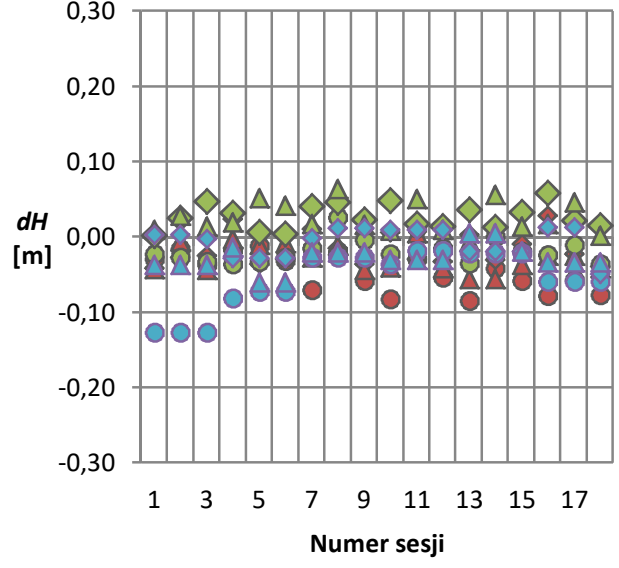

- Punkt 1 - GMV $\diamond$ Punkt 2 - GMV $\triangle$ Punkt 3-GMV O Punkt 1 - CSRS $\triangle$ Punkt 2 - CSRS $\triangle$ Punkt 3 - CSRS

O Punkt 1 - APPS $\triangle$ Punkt 2 - APPS $\triangle$ Punkt 3 - APPS

Rys. 8. Odchyłka współrzędnej wysokości $H$ pozycji dla sesji 2 godz.

Fig. 8. Deviation of the height coordinate $H$ of position for $2 \mathrm{~h}$ sessions

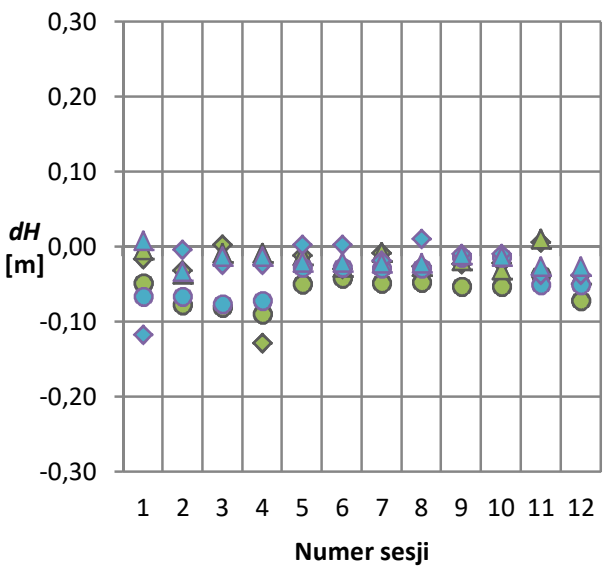

Punkt 1 - GMV Punkt 2 - GMV $\triangle$ Punkt 3 - GMV OPunkt 1 - CSRS $\triangle$ Punkt 2 - CSRS $\triangle$ Punkt 3 - CSRS OPunkt 1 - APPS $\diamond$ Punkt 2 - APPS $\triangle$ Punkt 3 - APPS

Rys. 10. Odchyłka współrzędnej wysokości $H$ pozycji dla sesji 3 godz.

Fig. 10. Deviation of the height coordinate $H$ of position for $3 \mathrm{~h}$ sessions 
Tabela 5. Statystyki współrzędnej pionowej $H$ pozycji na punktach osnowy pomiarowej dla różnej długości sesji

Table 5. Statistics of the height coordinate $H$ of positions on points of test network for different time session

\begin{tabular}{|c|c|c|c|c|c|c|c|c|c|c|}
\hline \multirow{2}{*}{$\begin{array}{c}\text { Nazwa } \\
\text { usługi }\end{array}$} & $\begin{array}{c}\text { Długość } \\
\text { sesji } \\
{[\mathbf{h}]}\end{array}$ & \multicolumn{3}{|c|}{$\begin{array}{c}\text { Średnie odchyłki } \\
|\boldsymbol{H}|[\mathbf{c m}]\end{array}$} & \multicolumn{3}{c|}{$\begin{array}{c}\text { Maksymalne odchylki } \\
|\boldsymbol{H}|[\mathbf{c m}]\end{array}$} & \multicolumn{3}{c|}{$\begin{array}{c}\text { Udzial procentowy } \\
\text { wrzedziale } \pm \mathbf{6} \mathbf{c m}[\%]\end{array}$} \\
\cline { 3 - 12 } & $\mathbf{1}$ & $\mathbf{2}$ & $\mathbf{3}$ & $\mathbf{1}$ & $\mathbf{2}$ & $\mathbf{3}$ & $\mathbf{1}$ & $\mathbf{2}$ & $\mathbf{3}$ \\
\hline GMV & 0.5 & 9.3 & 10.4 & 7.1 & 31.5 & 43.4 & 18.9 & 37 & 40 & 48 \\
\hline APPS & 0.5 & 6.8 & 13.0 & 8.3 & 24.6 & 26.7 & 19.8 & 39 & 28 & 33 \\
\hline CSRS & 0.5 & 5.2 & 5.2 & 3.5 & 15.8 & 29.6 & 13.7 & 65 & 71 & 82 \\
\hline GMV & 1 & 8.3 & 6.1 & 4.4 & 14.5 & 17.5 & 16.6 & 25 & 44 & 78 \\
\hline APPS & 1 & 6.3 & 4.4 & 4.5 & 11.1 & 14.1 & 18.7 & 44 & 61 & 75 \\
\hline CSRS & 1 & 3.6 & 3.2 & 3.1 & 10.4 & 8.5 & 7.7 & 81 & 83 & 83 \\
\hline GMV & 2 & 4.7 & 2.5 & 2.9 & 8.4 & 4.1 & 5.5 & 72 & 100 & 100 \\
\hline APPS & 2 & 5.5 & 1.5 & 2.9 & 12.6 & 4.8 & 5.9 & 67 & 100 & 100 \\
\hline CSRS & 2 & 2.2 & 2.7 & 2.6 & 3.6 & 5.9 & 6.4 & 100 & 100 & 94 \\
\hline GMV & 3 & 5.8 & 2.9 & 1.9 & 8.9 & 12.8 & 3.7 & 67 & 92 & 100 \\
\hline APPS & 3 & 4.3 & 2.5 & 1.9 & 7.6 & 11.8 & 3.3 & 83 & 92 & 100 \\
\hline CSRS & 3 & 1.4 & 2.0 & 2.8 & 4.0 & 4.6 & 3.9 & 100 & 100 & 100 \\
\hline GMV & 6 & 1.7 & 1.2 & 1.6 & 2.3 & 2.8 & 2.3 & 100 & 100 & 100 \\
\hline APPS & 6 & 1.3 & 0.7 & 2.1 & 2.0 & 1.5 & 3.2 & 100 & 100 & 100 \\
\hline CSRS & 6 & 2.9 & 2.3 & 3.2 & 3.2 & 2.8 & 3.5 & 100 & 100 & 100 \\
\hline
\end{tabular}

Przedstawione $\mathrm{w}$ [15] wyniki badań różnych permanentnych usług PPP w zależności od długości sesji obserwacyjnej pozwalają stwierdzić, że wyznaczanie pozycji pojedynczych punktów osnowy z dokładnością 2-4 $\mathrm{cm}$ można uzyskać już dla 2-godzinnych sesji pomiarowych. Powyższy wniosek sformułowano w oparciu o badania na tylko 5 sesjach pomiarowych. W niniejszym artykule ilość przebadanych sesji pomiarowych zwiększono do 420 na skutek podziału 6-godzinnych obserwacji. Większa liczebności próby badawczej pozwala na podstawie rezultatów przedstawionych na (Rys. 9, 10) oraz (Tab. 4, 5) stwierdzić, że z opracowania 3-godzinnych sesji obserwacyjnych dla usługi APPS i CSRS od $83 \%$ do $100 \%$ wyznaczonych wypadkowych horyzontalnych pozycji znalazło się $\mathrm{w}$ przedziale $\pm 3 \mathrm{~cm}$ od pozycji referencyjnej i składowych wysokości zmieściło się w przedziale $\pm 6 \mathrm{~cm}$ od pozycji referencyjnej.

Wyniki obliczeń w postaci wartości odchyłek wartości bezwzględnej odległości zredukowanej między punktami osnowy pomiarowej 1-2, 2-3 i 3-1 dla różnych długości sesji przedstawiono odpowiednio na (Rys. 11, 13, 15). Natomiast wartości bezwzględne odchyłek wysokości względnej między punktami osnowy pomiarowej 1-2, 2-3 i 3-1 dla różnych długości sesji przedstawiono odpowiednio na (Rys. 12, 14, 16). Rodzaj zastosowanej permanentnej usługi inter- 
netowej PPP wyróżniono kolorem. Porównując zamieszczone wykresy (Rys. 11, 13, 15), można zauważyć dla sesji co najmniej 1-godzinnych wyższą dokładność wyznaczania odległości zredukowanej między punktami 1-2. Różnice wielkości referencyjnych w stosunku do obliczonych między punktami 1-2 (Tab. 6) dla sesji co najmniej 1-godzinnych wynoszą: maksimum $0,189 \mathrm{~m}$ oraz minimum $0,013 \mathrm{~m}$. Natomiast analizując wykresy zamieszczone na (Rys. 12, 14, 16), dla sesji co najmniej 1-godzinnych można zauważyć wyższą dokładność wyznaczania wysokości względnej między punktami 3-1. W takich przypadkach różnice wielkości referencyjnych w stosunku do obliczonych między punktami 3-1 (Tab. 7) wynoszą: maksimum $0,169 \mathrm{~m}$ oraz minimum $0,015 \mathrm{~m}$.

Biorąc pod uwagę sesje co najmniej 1-godzinne najmniejsze wartości odchyłek maksymalnych przy wyznaczaniu długości zredukowanej i wysokości względnej uzyskano przy użyciu usług CSRS i APPS. Przy czym wartości odchyłek maleją na korzyść usługi CSRS wraz ze skróceniem długości sesji pomiarowej $($ Tab. 6,7$)$. Największe wartości odchyłek maksymalnych przy wyznaczaniu długości zredukowanej (Tab. 6) można zaobserwować w przypadku sesji nie dłuższych niż 2-godzinne dla usługi GMV. Dla sesji co najmniej 2-godzinnych można zauważyć coraz mniejsze różnice między wartościami odchyłek maksymalnych badanych usług PPP przy wyznaczaniu długości zredukowanej oraz wysokości względnej (Tab. 6, 7). Korzystając z usług APPS lub CSRS dla sesji dwugodzinnych przy wyznaczaniu wielkości względnych między punktami osnowy pomiarowej 1-2 i 2-3 od $89 \%$ do $100 \%$ wyznaczonych długości zredukowanych pozycji znalazło się w przedziale $\pm 6 \mathrm{~cm}$ od pozycji referencyjnej, a 100\% obliczonych wysokości względnych zmieściło się w przedziale $\pm 10 \mathrm{~cm}$ od pozycji referencyjnej.

Po analizie wyników prezentowanych na (Rys. 12, 14, 16) oraz (Tab. 6), można stwierdzić, że dla co najmniej 1-godzinnych sesji obserwacyjnych najmniejsze odchyłki wysokości względnej mają miejsce na odległości zredukowanej między punktami 1-2. Natomiast między parą punktów 2-3 i 3-1 odchyłki odległości zredukowanej są większe. Zależność ta może wynikać z usytuowania punktów osnowy pomiarowej względem orientacji osi układu współrzędnych. Kierunek boku trójkąta osnowy 1-2 zbliżony jest do kierunku północy, natomiast kierunki dwóch pozostałych boków 2-3 oraz 3-1 zbliżone są do kierunku wschodniego. Składowa północna najczęściej charakteryzuje się większą dokładnością (Rys. 3, 5, 7), co korzystnie wpływa na zmniejszenie odchyłek maksymalnych na odległości zredukowanej 1-2.

Na podstawie przedstawionych w [15] badań różnych permanentnych usług PPP w zależności od długości sesji obserwacyjnej stwierdzono, że już godzinne sesje pomiarowe umożliwiają wyznaczenie odległości zredukowanej lub wysokości względnej dla boków osnowy o kierunku zbliżonym do północnego z dokładnością 1-3 cm, a boków o kierunku zbliżonym do wschodniego z dokładnością 2-6 cm. Powyższy wniosek sformułowano w oparciu o badania na tylko 5 sesjach pomiarowych. W niniejszym artykule ilość przebadanych sesji pomia- 
rowych zwiększono do 420. Wzrost ilości sesji uzyskano z podziału 6-godzinnych obserwacji.

Dużo większa liczebności próby badawczej pozwala na podstawie rezultatów przedstawionych na (Rys. 11, 13,15) oraz (Tab. 6) stwierdzić, że już 3-godzinne sesje pomiarowe umożliwiają wyznaczenie odległości zredukowanej dla boków osnowy o kierunku zbliżonym do północnego z dokładnością 2-4 cm, a boków o kierunku zbliżonym do wschodniego z dokładnością 4-8 cm.

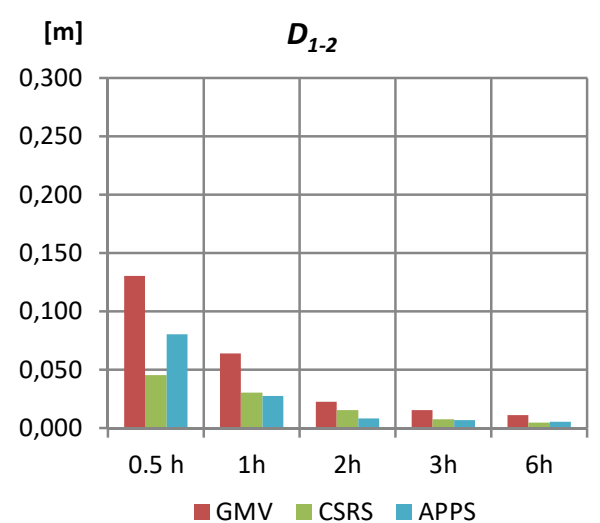

Rys. 11. Odchyłka odległości zredukowanej $D$ między punktami 1-2 dla różnej długości sesji

Fig. 11. Deviation of the horizontal distance $D$ between points 1-2 for different time session

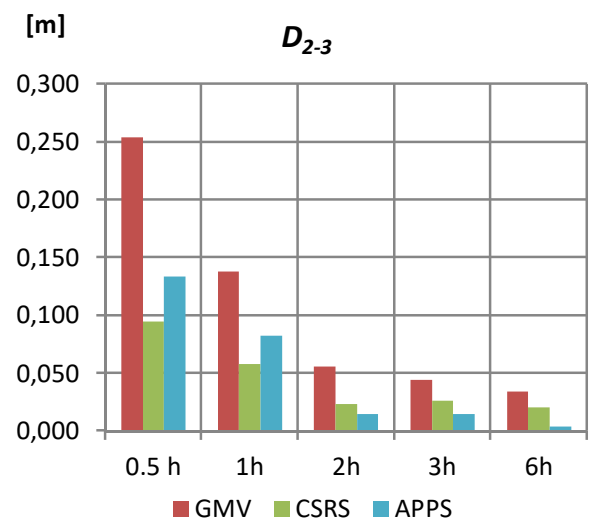

Rys. 13. Odchyłka odległości zredukowanej $D$ między punktami 2-3 dla różnej długości sesji

Fig. 13. Deviation of the horizontal distance $D$ between points 2-3 for different time session

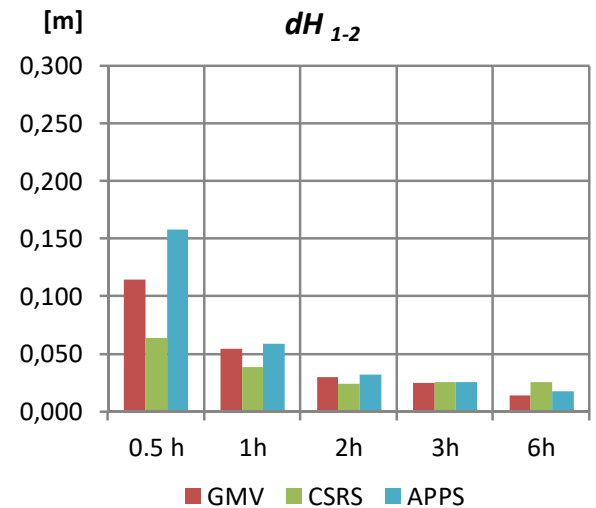

Rys. 12. Odchyłka wysokości względnej $d H$ między punktami 1-2 dla różnej długości sesji

Fig. 12. Deviation of the relative height $d H$ between points 1-2 for different time session

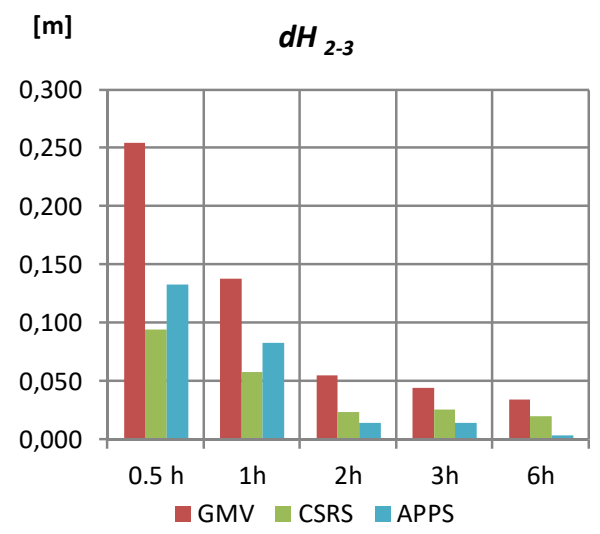

Rys. 14. Odchyłka wysokości względnej $d H$ między punktami 2-3 dla różnej długości sesji

Fig. 14. Deviation of the relative height $d H$ between points 2-3 for different time session 


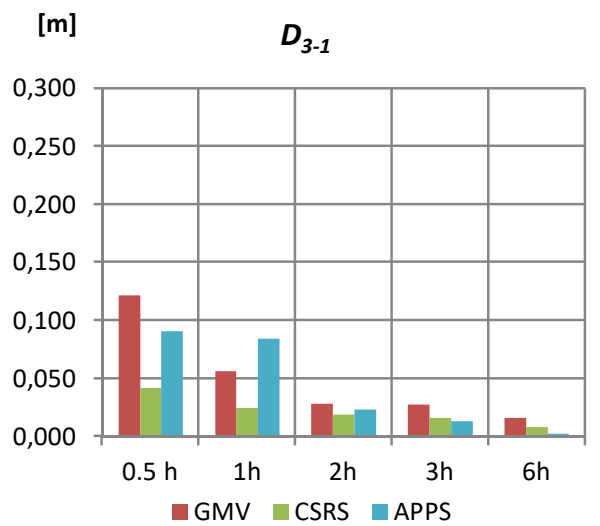

Rys. 15. Odchyłka odległości zredukowanej $D$ między punktami 3-1 dla różnej długości sesji

Fig. 15. Deviation of the horizontal distance $D$ between points 3-1 for different time session

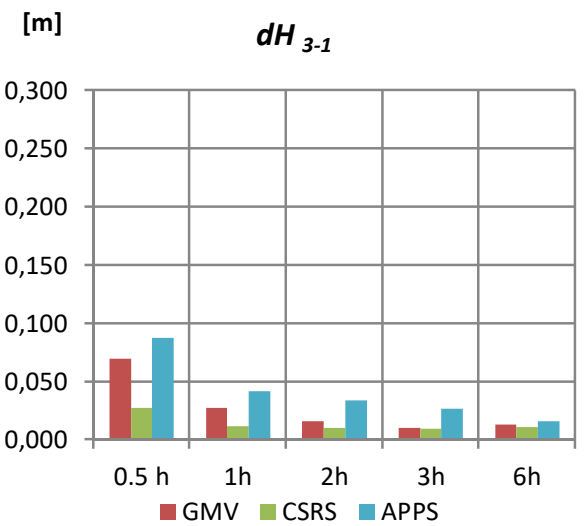

Rys. 16. Odchyłka wysokości względnej $d H$ między punktami 3-1 dla różnej długości sesji tween points 3-1 for different time session

Tabela 6. Statystyki odległości zredukowanej $D$ między punktami osnowy pomiarowej dla różnej długości sesji

Table 6. Statistics for the horizontal distance $D$ between points of test network for different time session

\begin{tabular}{|c|c|c|c|c|c|c|c|c|c|c|}
\hline \multirow{2}{*}{$\begin{array}{l}\text { Nazwa } \\
\text { uslugi }\end{array}$} & \multirow{2}{*}{$\begin{array}{c}\text { Długość } \\
\text { sesji } \\
{[h]}\end{array}$} & \multicolumn{3}{|c|}{$\begin{array}{l}\text { Średnie odchyłki } \\
\qquad|D|[\mathrm{cm}]\end{array}$} & \multicolumn{3}{|c|}{$\begin{array}{c}\text { Maksymalne odchylki } \\
\qquad|D|[\mathrm{cm}]\end{array}$} & \multicolumn{3}{|c|}{$\begin{array}{c}\text { Udzial procentowy } \\
\text { w przedziale } \pm 6 \mathrm{~cm}[\%]\end{array}$} \\
\hline & & $1-2$ & $2-3$ & 3-1 & $1-2$ & $2-3$ & $3-1$ & $1-2$ & $2-3$ & $3-1$ \\
\hline GMV & 0.5 & 13.1 & 25.4 & 12.1 & 57.4 & 100.2 & 45.1 & 34 & 7 & 29 \\
\hline APPS & 0.5 & 8.0 & 13.3 & 9.1 & 29.0 & 45.2 & 16.9 & 33 & 50 & 33 \\
\hline CSRS & 0.5 & 4.6 & 9.5 & 4.2 & 14.7 & 37.7 & 21.4 & 71 & 43 & 74 \\
\hline GMV & 1 & 6.5 & 13.8 & 5.7 & 18.9 & 47.9 & 25.4 & 56 & 24 & 65 \\
\hline APPS & 1 & 2.8 & 8.3 & 8.4 & 11.3 & 25.7 & 21.2 & 92 & 39 & 56 \\
\hline CSRS & 1 & 3.1 & 5.8 & 2.5 & 7.0 & 16.2 & 9.9 & 97 & 61 & 89 \\
\hline GMV & 2 & 2.3 & 5.5 & 2.8 & 5.0 & 10.1 & 8.0 & 100 & 56 & 89 \\
\hline APPS & 2 & 0.8 & 1.4 & 2.3 & 1.8 & 7.5 & 7.9 & 100 & 89 & 72 \\
\hline CSRS & 2 & 1.5 & 2.3 & 1.9 & 3.0 & 5.6 & 4.2 & 100 & 100 & 100 \\
\hline GMV & 3 & 1.6 & 4.4 & 2.8 & 3.0 & 6.8 & 5.9 & 100 & 100 & 100 \\
\hline APPS & 3 & 0.7 & 1.5 & 1.3 & 1.8 & 6.7 & 6.6 & 100 & 83 & 83 \\
\hline CSRS & 3 & 0.8 & 2.6 & 1.6 & 2.1 & 4.8 & 3.9 & 100 & 100 & 100 \\
\hline GMV & 6 & 1.1 & 3.4 & 1.6 & 1.6 & 3.9 & 2.0 & 100 & 100 & 100 \\
\hline APPS & 6 & 0.6 & 0.4 & 0.3 & 1.3 & 0.7 & 0.4 & 100 & 100 & 100 \\
\hline CSRS & 6 & 0.5 & 2.0 & 0.8 & 1.3 & 2.3 & 1.0 & 100 & 100 & 100 \\
\hline
\end{tabular}


Analizując wyniki na (Rys. 12, 14, 16) oraz (Tab. 7) można zauważyć, że dla co najmniej 3-godzinnych sesji obserwacyjnych wysokość względną można wyznaczyć z dokładnością 2-6 cm. Najmniejsze wartości odchyłek maksymalnych wysokości względnej uzyskały usługa APPS i CSRS.

Tabela 7. Statystyki wysokości względnej $d H$ między punktami osnowy pomiarowej dla różnej długości sesji

Table 7. Statistics for the relative height $d H$ between points of test network for different time session

\begin{tabular}{|c|c|c|c|c|c|c|c|c|c|c|}
\hline \multirow[t]{2}{*}{$\begin{array}{l}\text { Nazwa } \\
\text { usługi }\end{array}$} & \multirow{2}{*}{$\begin{array}{c}\text { Długość } \\
\text { sesji } \\
{[h]}\end{array}$} & \multicolumn{3}{|c|}{$\begin{array}{l}\text { Średnie odchyłki } \\
\qquad|d H|[\mathrm{cm}]\end{array}$} & \multicolumn{3}{|c|}{$\begin{array}{l}\text { Maksymalne odchyłki } \\
\qquad|d H|[\mathrm{cm}]\end{array}$} & \multicolumn{3}{|c|}{$\begin{array}{c}\text { Udzial procentowy } \\
\text { w przedziale } \pm 10 \mathrm{~cm} \\
{[\%]}\end{array}$} \\
\hline & & $1-2$ & $2-3$ & $3-1$ & $1-2$ & $2-3$ & $3-1$ & $1-2$ & $2-3$ & 3-1 \\
\hline GMV & 0.5 & 11.5 & 25.4 & 6.9 & 42.3 & 35.0 & 33.7 & 59 & 56 & 79 \\
\hline APPS & 0.5 & 15.8 & 16.9 & 8.7 & 38.9 & 34.0 & 23.9 & 39 & 39 & 61 \\
\hline CSRS & 0.5 & 6.4 & 6.9 & 2.8 & 34.7 & 34.1 & 10.3 & 76 & 81 & 99 \\
\hline GMV & 1 & 5.4 & 13.8 & 2.7 & 18.8 & 18.7 & 11.9 & 82 & 85 & 97 \\
\hline APPS & 1 & 5.9 & 6.3 & 4.2 & 16.9 & 17.3 & 16.9 & 75 & 75 & 89 \\
\hline CSRS & 1 & 3.9 & 4.1 & 1.2 & 9.6 & 12.7 & 3.5 & 100 & 94 & 100 \\
\hline GMV & 2 & 3.0 & 5.5 & 1.6 & 5.9 & 5.6 & 5.8 & 100 & 100 & 100 \\
\hline APPS & 2 & 3.2 & 2.5 & 3.4 & 5.9 & 4.9 & 6.8 & 100 & 100 & 100 \\
\hline CSRS & 2 & 2.5 & 2.6 & 1.0 & 5.6 & 5.2 & 2.5 & 100 & 100 & 100 \\
\hline GMV & 3 & 2.5 & 4.4 & 1.0 & 12.6 & 12.6 & 2.2 & 92 & 92 & 100 \\
\hline APPS & 3 & 2.6 & 1.2 & 2.7 & 4.3 & 2.8 & 4.2 & 100 & 100 & 100 \\
\hline CSRS & 3 & 2.5 & 1.6 & 0.9 & 5.5 & 4.3 & 2.1 & 100 & 92 & 100 \\
\hline GMV & 6 & 1.4 & 0.7 & 1.4 & 2.8 & 1.6 & 1.9 & 100 & 100 & 100 \\
\hline APPS & 6 & 1.8 & 0.6 & 1.6 & 2.8 & 1.2 & 2.6 & 100 & 100 & 100 \\
\hline CSRS & 6 & 2.6 & 1.5 & 1.1 & 4.1 & 2.8 & 1.5 & 100 & 100 & 100 \\
\hline
\end{tabular}

\section{Podsumowanie i wnioski}

Przedstawione powyżej opracowanie dotyczy analizy dokładności techniki precyzyjnego pozycjonowania w zależności od długości sesji obserwacyjnej oraz rodzaju zastosowanej permanentnej usługi internetowej PPP. W wyniku badań wyznaczono współrzędne, odległości zredukowane i wysokości względnej dla trójkątnej osnowy pomiarowej. Obliczenia wykonano z wykorzystaniem trzech permanentnych usług tj: APPS, CSRS-PPP, GMV magicGNSS. Natomiast przy obliczaniu odchyłek dla odległości zredukowanej $D$ i wysokości względnej $d H$ za wartości referencyjne przyjęto wyniki pomiarów wykonanych stacją laserową Leica TDRA 6000. Przy wyznaczaniu błędów wypadkowej horyzontalnej $N E$ i składowej pionowej $H$ na punktach osnowy pomiarowej jako wielkości porównawcze posłużyło opracowanie obserwacji w trybie post- 
processingu z 6 najbliższych stacji referencyjnych sieci Leica SmartNet. Chcąc uzyskać większą dokładność wielkości referencyjnych niż subcentymetrowa należałoby wykonać dobowe sesje obserwacyjne, które dają dokładność milimetrową.

Na podstawie rezultatów przedstawionych na (Rys. 9, 10) oraz (Tab. 4, 5) można stwierdzić, że możliwe jest uzyskanie wypadkowej horyzontalnej pozycji o dokładności $3 \mathrm{~cm}$ i składowej wysokości o dokładności $6 \mathrm{~cm} \mathrm{z}$ opracowania 3-godzinnych sesji obserwacyjnych.

Natomiast analiza wyników zaprezentowanych na (Rys. 11, 13, 15) oraz (Tab. 6) pozwala stwierdzić, że 3-godzinne sesje pomiarowe umożliwiają wyznaczenie odległości zredukowanej dla boków osnowy o kierunku zbliżonym do północnego z dokładnością 2-3 cm, a boków o kierunku zbliżonym do wschodniego z dokładnością 4-7 cm. Biorąc pod uwagę rezultaty na (Rys. 12, 14, 16) oraz (Tab. 7) można powiedzieć, że 3-godzinne sesje pomiarowe umożliwiają wyznaczenie wysokości względnej z dokładnością $2-7 \mathrm{~cm}$. W celu uzyskania wyższych dokładności należałoby wykonać dłuższą sesję obserwacyjną.

Przedstawiony zakres badań można rozszerzyć o włączenie do sesji pomiarowych dodatkowych konstelacji satelitów jak: GLONASS, Galileo, BeiDou co mogłoby wpłynąć na skrócenie czasu trwania sesji pomiarowej w porównaniu z obserwacjami z pojedynczej konstelacji GPS przy oczekiwaniu takiego samego poziomu dokładności.

\section{Literatura}

[1] J. Kouba, P. Héroux, Precise point positioning using IGS orbit and clock products, GPS Solutions, 5, 2, 2001, 12-28.

[2] Y. Gao, K. Chen, Performance analysis of precise point positioning using rea-time orbit and clock products, Journal of Global Positioning Systems, 3, 1-2, 2004, 95-100.

[3] R.F. Leandro, M.C. Santos, R.B. Langley, Analyzing GNSS data in precise point positioning software, GPS Solutions, 15, 1, 2009, 1-13.

[4] Ch. Cai, Y. Gao, Precise point positioning using combined GPS and GLONASS observations, Journal of Global Positioning Systems, 6, 1, 2007, 13-22.

[5] Choy S. „High accuracy precise point positioning using a single frequency GPS receiver", J Appl Geod nr 5/2011, s. 59-69.

[6] Zumberge J.F., Heflin M.B., Jefferson D.C., Watkins M.M., Webb F.H. „Precise point positioning for the efficient and robust analysis of GPS data from large networks", J. Geophys. Res., vol. 102(B3), 1997, s. 5005-5017.

[7] Gao Y. „Precise point positioning and its challenges, aided GNSS and signal tracking”, Inside GNSS, nr 1(8)/2011, s. 16-18.

[8] Geng J., Meng X., Dodson A.H., Teferle F.N. „, Integer ambiguity resolution in precise point positioning: method comparison", J. Geod nr 84(9)/2010, s. 569-581.

[9] Rogowski J. B., Figurski M. „Ziemskie systemy i układy odniesienia oraz ich realizacje. W: Nowe obowiązujące niebieskie i ziemskie systemy i układy odniesienia oraz ich wzajemne relacje.", Warszawa, IGiK, 2004, s. 37-68. 
[10] Stępniak K., Wielgosz P., Paziewski J. „Badania dokładności pozycjonowania techniką PPP w zależności od odległości sesji obserwacyjnej oraz wykorzystanych systemów pozycjonowania satelitarnego", Biuletyn WAT, nr 1/2012, s. 429-450.

[11] Guo Q., „Precision comparison and analysis of four online free PPP services in static positioning and tropospheric delay estimation", GPS Solutions, 2015, Vol. 19, Issue 4, p. 537-544.

[12]Krzan G., Dawidowicz K., Świątek K., „Analysis of current position determination accuracy in natural resources canada precise point positioning service", Artificial Satellites, 2013, 48(3), pp. 111-124.

[13]Dawidowicz K., Krzan G., „Coordinate estimation accuracy of static precise point positioning using on-line PPP service, a case study", Acta Geodaetica et Geophysica, 2014, Vol. 49, Issue 1, , p. 37-55.

[14]Abdallah, A., Schwieger, V. „Static GNSS precise point positioning using free online services for Africa”, 2016, Survey Review 48(346), pp. 61-77.

[15] Malinowski M., Kwiecień J. „A comparative study of precise point positioning (PPP) accuracy using online services", Reports on Geodesy and Geoinformatics, Vol. 102, 2016, p. 15-31.

Podziękowania

Chciałbym wyrazić podziękowanie firmie Effigis za nieodpłatne udostępnienie oprogramowania OnPOZ EzSurv oraz podmiotom odpowiedzialnym za zarzadzanie $i$ utrzymanie permanentnych ustug internetowych PPP, które przyczynity się do realizacji badań przedstawionych w niniejszym artykule.

\section{PRECISE POINT POSITIONING (PPP) ACCURACY USING ONLINE WEB SERVICES}

\section{S u m m a r y}

Precise Point Positioning (PPP) is a technique used to determine high accuracy position with a single GNSS receiver. May be an alternative solution to differential measurements, where maintaining a connection with a single Real Time Kinematic (RTK) station or a regional Real Time Network (RTN) of reference stations is necessary. This situation is especially common in areas with poorly developed infrastructure of ground stations. This paper presents the results of a comparative analysis of accuracy of absolute determination of position from observations which last between 0,5 to 6 hours with the use of four permanent free online web services which execute calculations with PPP technique such as: Automatic Precise Positioning Service (APPS), Canadian Spatial Reference System Precise Point Positioning (CSRS-PPP), GNSS Analysis and Positioning Software (GAPS) and magicPPP - Precise Point Positioning Solution (magicGNSS). For each point of test network, calculations were made using solely GPS observations and taking into account Final products. An evaluation of the impact on the accuracy of simultaneous positioning of three points test network on the change of the horizontal distance and the relative height difference between measured triangle vertices was also conducted.

Keywords: GPS, APPS, CSRS-PPP, GMV, magicGNSS 